\title{
Reinventing Higher Education Bureaucracy through Entrepreneurial Values
}

\author{
Munirul Abidin \\ Educational Faculty, Universitas Islam Negeri Maulana Malik Ibrahim Malang, Indonesia
}

Received August 6, 2020; Revised October 20, 2020; Accepted October 27, 2020

\section{Cite This Paper in the following Citation Styles}

(a): [1] Munirul Abidin, "Reinventing Higher Education Bureaucracy through Entrepreneurial Values," Universal Journal of Educational Research, Vol. 8, No. 12, pp. 6482-6490, 2020. DOI: 10.13189/ujer.2020.081213.

(b): Munirul Abidin (2020). Reinventing Higher Education Bureaucracy through Entrepreneurial Values. Universal Journal of Educational Research, 8(12), 6482-6490. DOI: 10.13189/ujer.2020.081213.

Copyright $\mathrm{C} 2020$ by authors, all rights reserved. Authors agree that this article remains permanently open access under the terms of the Creative Commons Attribution License 4.0 International License

\begin{abstract}
Today, higher education (HE) has experienced significant changes in various fields. Universities that were previously only places to transfer knowledge, research, and community services have turned into business institutions similar to companies. Competition between universities is inevitable, encouraging every university to help the community get their sympathy and trust. One of them is reinventing higher education bureaucracy. This paper aims to explain the characteristics of Higher Education entrepreneurial bureaucracy and the implementation of entrepreneurial values in improving HE's bureaucratic performance. The study was conducted at three universities in the city of Malang Indonesia using a qualitative approach. Data were collected through observation and an in-depth interview method and analyzed through three stages: necessary coding, co-occurrence, and clustering techniques. This study found several entrepreneurial values that applied to universities in developing an entrepreneurial bureaucratic system. The implementation of entrepreneurial values into HE bureaucracy provides space for them to create and bring innovative services to the community more flexibly, fast, and accountable. This study also revealed several strategic steps taken by universities in implementing entrepreneurial values and reinventing their bureaucracy. The research results also display several theoretical implications illustrate that an entrepreneurship orientation goes hand in hand with a growth orientation.
\end{abstract}

Keywords Entrepreneurship, Bureaucracy, Higher Education, Reinventing

\section{Introduction}

Higher education is an institution that has three main missions: research, teaching, and community service [1], [2]. According to Perkin [3], the three main missions refer to three aspects of knowledge, namely, acquisition, transmission, and application. Knowledge is obtained or explored through the research process and transferred from one generation to the next generation to maintain them able to survive. Knowledge does not only become a theory that develops from book to book, but also developed through the research and teaching process in universities [4].

Higher education has a complex organization. Like other organizations, universities have a hierarchical goal, system, and structure [5]. The tertiary institution has employees who work on certain tasks, the decision-making process that determines the institution's policies, and there is a bureaucratic administration that handles routine matters [6].

However, higher education also has many different characteristics from other organizations [7]. Like other public institutions, higher education is a unique organization, different from industrial organizations, government bureaucracy, and business organizations [8]. Most organizations are goal-oriented [9]. Consequently, they can create flexible decision structures to achieve their stated goals. Business organizations want to get profit, and government bureaucracy has to serve the community's interests, hospitals trying to treat the sick, and so on. While universities sometimes have ambiguous goals [10], they have to make complicated decisions accompanied by uncertainty and conflict [11].

There are no colleges that have the same goal. They have 
different goals and often try everything on everyone. Because their main goals are not clear, they are also challenging to reject the new goals that arise. Gross [12] analyzed faculty and administrators' goals at most American universities and obtained very astonishing results. He found more than 40 different goals between one college and another. The number of different goals is the same as the number of universities in America.

Another characteristic of higher education bureaucracy is that they are vulnerable to the environment. Almost all organizations always interact with their social environment to be able to exist. Indeed no organization is autonomous in determining its steps, but it could be that one organization is more independent than other organizations [13]. The autonomy of an organization when dealing with its environment is one of the essential determinants for determining how it will operate. Economics, free markets, business firms, and industries have a substantial degree of autonomy. Although they must follow government regulations and serve their customers' demands, they are primarily agents who are free to respond to market needs rather than government control. On the other hand, some organizations appear to be free but are, in fact, always suppressed by their environment [14]. For example, state schools, basically they are always supervised and pressured by the people.

The tertiary institution began to move from an independent organization to a co-opted organization. In some cases, tertiary institutions isolated from their surroundings. But lately, external forces have started to pressure universities [5]. Faculty and administrators lose their control over the curriculum, goals, and daily activities of the institution. In the next stage, academic professionals gradually lose their autonomy until they become like a laborer who does everything under the bureaucracy [7].

Indeed, since the acceptance of bureaucracy's concept into organizational arrangements, the bureaucratic system was quickly used in regulating various forms of organization, both private and government. The bureaucracy system is used in managing corporate or industrial organizations and government organizations, including education [15]. Almost all educational institutions implement a bureaucratic system to manage household affairs, both related to academic and non-academic issues. Although experts call the education bureaucracy different names, all of them recognize administration in the management of schools or colleges [16] referring to the administration in educational institutions as professional bureaucracy. The organizational structure in the world of education is "flat," in which most power is set aside because of professionalism. Leadership in a professional bureaucracy only function to deal with disturbances, maintain or limit tasks related to professionalism.

In Indonesia, the idea of an entrepreneurial university has long been echoed. This program involves several ministries and departments in Indonesia, ranging from the Minister of Education, the Minister of Industry, the Minister of Manpower, and so on, which touched both macro and microprograms and goals [17]. In general, this idea was influenced by the New Public Management Reform (NPMR)'s global thought in several developed countries [18]. The idea was initiated by selecting several universities as initiations and pilots to implement entrepreneurial university programs, such as Brawijaya University and the Bandung Institute of Technology (ITB). In 2012, through the Ministry of Research, Technology, and Higher Education, the Government referred to Law Number 12 of 2012 on Higher Education, which describes higher education governance towards entrepreneurial-based universities. To support the program, in 2014, referring to Law no. 12 2012, the Government issued Government Regulation No. 4 of 2014 Article 27 concerning the pattern of management of state universities into three status:

1. Non-Tax State Revenue of State University (Regular university).

2. State University with the way of financial management of public service agencies (BLU university).

3. A public university with an autonomous pattern of the regulation (PTN-BH).

Each of these higher education groups has a different character and financial management. Entrepreneurial university is directed at the second or third type of management pattern [19].

Several studies on entrepreneurial universities in Indonesia have also been carried out. Sakapurnama et al. [20] examined how the Bandung Institute of Technology (ITB) implemented entrepreneurship education. The research only describes ITB's vision and mission, entrepreneurial culture, and government and industry support. Several other studies were also conducted, such as those undertaken by Abduh et al. [21], Aldianto [22], Mahendra et al. [23] and Yulastri \& Hidayat [24], all of which were directed at strategies to form an entrepreneurial character. Research that describes the strategy of higher education in building entrepreneurial bureaucracy is still rarely conducted. There are several studies on this issue, such as conducted by Qurtubi [25], Saefullah [26], and Sakapurnama [27], which studied reinventing higher education in Indonesia. These studies do not specifically explain the strategy of higher education in building an entrepreneurial bureaucracy. They touched only on the implementation of entrepreneurial education and its challenges in Indonesia. Therefore, this study will specify two research focuses that have not been studied in several previous studies, namely:

- What values are applied in building an entrepreneurial-based bureaucracy? 
- What strategies are used by universities in entrepreneurial bureaucracy?

\section{Literature Review}

Drucker [28] explains that the characteristics of an entrepreneur are (1) always looking for a change, (2) trying to follow and adjust to change, and (3) using it as an opportunity. While Cole [29] suggested several characteristics of entrepreneurs are: (1) Entrepreneurs have an enthusiastic vision and a strong drive for entrepreneurship. (2) The entrepreneur's vision usually driven by a collection of specific ideas combined, which are not on the market. (3) All blueprints to realize the image are clear, but the details are not precise, flexible, and evolved. (4) Entrepreneurs enthusiastically promote their idea. (5) With perseverance and limitations, entrepreneurs develop strategies to turn their vision into reality. (6) Entrepreneurs responsible to bring their vision to success. (7) Entrepreneurs carefully calculate risks. They calculate costs, markets, customer needs, and persuade others to join in and help. (8) Entrepreneurs usually have positive thoughts and are decision-makers. Whereas Hornaday and Aboud [30] explained that the characteristics of an entrepreneur are: (1) The desire to pursue achievement, (2) Pleased with challenges, (3) Knowing both technical and managerial jobs, (4) Having an attitude and good leadership behavior, (5) Having full power in managing the business, (6) Innovative.

Baldridge et al., [5] recorded the notes of sociologists who make several important observations about the characteristics of professional workers wherever they work. Their features are as follows; (1) Professionals need autonomy at work. (2) Professionals have divided loyalties. They have a "cosmopolitan" tendency and have high commitment to their "professional friends" at the national level, which sometimes outperform their dedication to local organizations. (3) There is an intense pressure between the values of professionalism and the expectations of the bureaucracy in the organization. This can intensify conflicts between professional workers and organizational managers. (4) Professionals need evaluation groups for their work. They believe that only their colleagues can criticize their performance, and they reject evaluations from others, including those who are technically superior in the organizational hierarchy.

All of the above characteristics end up cutting traditional bureaucratic norms, rejecting their hierarchy, control structure, and management procedures. That's why different types of management needed in professional organizations. One way is to break up professional staff. It means that professionals are divided based on their respective professions into small groups. In this case, Clark [31] revealed that the dominance of individual professionals in tertiary institutions rarely occurs because, in tertiary institutions, there are professional groups that are relatively equal in number, making them controlled. If professionals are more dominant in the organization, the power in the organization will split between bureaucratic officials and professionals. Therefore the bureaucracy applied in regulating schools in general and higher education, in particular, is a professional bureaucracy that is flat and flexible.

However, several other experts say that the Weberian bureaucratic model is very likely to be applied in higher education organizations. According to Stroup [32], there are many things in the higher education bureaucracy with the same characteristics as the Weberian bureaucracy model. In essence, competence is the criterion on which a person is appointed to a position. Its officials were appointed directly without an election. Official salaries are determined directly based on position. Officials have authority whose existence is recognized and respected. The duties of the officials are exclusive and do not carry out other tasks. The lifestyle of the organizational members centered on the organization. Security is guaranteed if it follows the system, and there are differences between individuals and organizations.

The application of weber bureaucracy in tertiary institutions' management makes bureaucracy in tertiary institutions stiff and inflexible [33]. Higher education is an institution that manages people who have tremendous and professional knowledge. An easy and flexible administration is needed in the management of higher education. The application of entrepreneurial-values in bureaucracy needed to move the rigid, unproductive, and increased economic value of the university bureaucracy system to a bureaucratic system that is flexible, productive, and of low financial cost, as contained in the principles of entrepreneurship. Individual efforts must be made by the managers of higher education to implement entrepreneurial values to increase bureaucratic productivity [34], [35].

Entrepreneurial-minded bureaucracy is not only running following rigid and routines. However, it is a bureaucracy that responds to change outside the administration while still paying attention to bureaucracy's principles. Osborne [36] called it an entrepreneurial bureaucracy, which moves various potential sources from an area with low productivity to higher productivity and greater yields. This paper aims to reveal the entrepreneurial values implemented in building a higher education bureaucracy and reinventing it toward entrepreneurial bureaucracy.

\section{Materials and Methods}

This study uses a qualitative approach because this research's object was the process and activities of people in implementing entrepreneurial values in higher education. The research object is in a natural condition. The data obtained are not in the form of numbers but words, sentences, and documents. The research object is not manipulated or given a particular treatment but in a natural 
condition. The data collected through interviews and analyzed inductively [37]. The case study design chosen because it was under the objectives of the study, to obtain an overview of the entrepreneurial values implemented in research subjects on natural settings with specific characteristics and to find variables that exist in real contexts related to the question of how and why [38].

This research was conducted in three major universities in Malang City Indonesia, namely Brawijaya University (UB), University of Muhammadiyah Malang (UMM), and UIN Maliki Malang. The three universities were chosen because they had exemplary achievements and were taken into account by the Indonesian people. UB is known as an entrepreneurial university and has made it a jargon for institutional development. The Ministry of National Education appointed it as one of the incubators in Indonesia's entrepreneurial campuses. All students are required to participate in entrepreneurial activities. The university provided the incubator program for students to practice the entrepreneurial activities managed by the campus [39]. UMM Malang was chosen as a research institution because it is a private higher education institution in Indonesia, which has developed rapidly in the last ten years. The progress made is not only in academics but also in business and entrepreneurship, such as hospitality, tourism, and agriculture. In terms of services, UMM has developed a legacy system, a kind of SMS gateway service, which can broadcast messages to lecturers and employees and send a single SMS. This web-based service can be accessed locally at the SMS.umm.ac.id domain. Functionally, this system can send available SMS and broadcast messages to groups. The groups are divided into two categories, employees and lecturers. The system can broadcast to all employees in the employee category, based on work units and groups that can be created manually. The system can post to all lecturers, faculty, department, and group, which can be created manually in the lecturer category [40]. UIN Maliki Malang is an Islamic higher education institution in Malang, which also has brilliant achievements. In the last ten years, the college has grown from college to university [41]. At a glance, the institution's progress can be seen from the shape of its beautiful and magnificent buildings. The opening of new lands for faculty and department development on 100 hectares of land is a witness to this higher education institution's progress. For the reasons above, the three institutions deserve to be chosen as objects of study in applying entrepreneurial values in the development of higher education bureaucracy.

Data collected through in-depth interview techniques to university managers consist of the rector, the vice of rector, officials, and lecturers at the college. The interviews were conducted with open-ended and unstructured questions. The data obtained in-depth information about the managers of tertiary institutions' efforts in applying entrepreneurial values in tertiary institutions. The participants of this study described in the following table:

Table 1. Demographic descriptive of participants

\begin{tabular}{ccc}
\hline No & Occupation & Frequency \\
\hline 1. & Rector & 3 \\
2. & Vice of rector & 6 \\
3. & Academic bureau & 3 \\
4. & Administration bureau & 3 \\
5. & Lecturer & 6 \\
\hline & Total & $\mathbf{2 1}$ \\
\hline
\end{tabular}

\subsection{Data Analysis}

In this study, data analyzed following the analysis process introduced by Namey (2008) through several stages: necessary coding, co-occurrence, and clustering techniques. In the first stage, structural coding, researchers transcribe all data obtained through interviews. The data read several times repeatedly to find essential points that support the study theme. In the second stage, co-occurrence, the researcher ranks the data according to categories, sub-themes, and ideas that appear in the data. The same points in the code that appears are grouped into one type or the same theme so that each system that seems to combine in the same group, category, or topic. In the next stage, the researcher connects one issue with another or one type with another type to find a significant theme, which is the central cluster of research findings [43].

\section{Result}

\subsection{Characteristics of HE Entrepreneurial Bureaucracy}

The data analysis process found several aspects of HE bureaucracy with the entrepreneurial idea. These characteristics are:

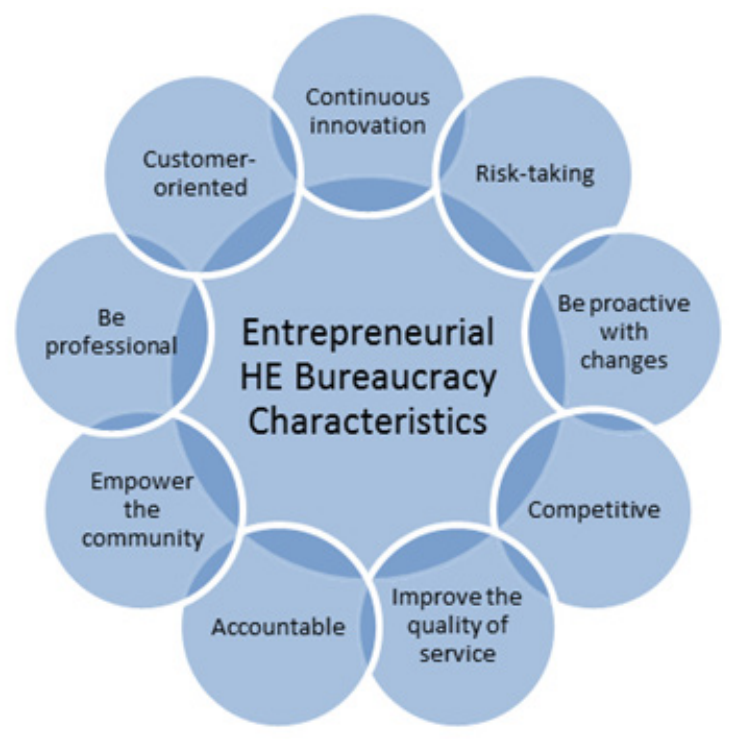

Figure 1. The attributes of entrepreneurial HE bureaucratic 


\subsubsection{Continuous Innovation}

One of the tertiary institutions characteristics that conduct entrepreneurial bureaucracy is HE that makes continuous innovation. Innovation is an integral part of an entrepreneurial-minded bureaucracy because, with constant innovation, HE will always look for new things to improve its bureaucratic system. Bureaucratic changes in HE realize in various services, both services in the academic and non-academic sectors.

\subsubsection{Be Proactive with Changes}

HE entrepreneurial bureaucracy is a bureaucracy that is always proactive with changes. Higher education bureaucracy must be sensitive to change because HE is the agent of change. As an agent of change, HE is not only responsive to change but must be prepared to make the change itself. HE must be able to be a pioneer for changes in society in various fields. When people experience stagnation, HE must take an active role in encouraging people to become better.

\subsubsection{Risk-taking}

HE entrepreneurial-minded bureaucracy is the bureaucracy that dares to take risks on policies adopted to improve services to the community. In terms of playing its role as an institution that serves the public at large, HE will confront various interests that are mutually reciprocating. HE bureaucracy with an entrepreneurial vision must be brave to make the best decisions even though it has to face significant societal risks. If the HE was afraid to take risks to develop institutions and improve services to the community, the institution will stagnant and not develop.

\subsubsection{Competitive}

HE bureaucracy with entrepreneurial insight must be competitive to compete with other educational institutions. Competitiveness is an essential character for HE to ensure the sustainability of the institution in the following years. Many higher education institutions eventually closed because they were unable to compete with other competing educational institutions. Competitive character is the primary key to higher education bureaucracy's success in maintaining its existence as an educational institution that exists in society. Competitive bureaucracy means bureaucracy that does not surrender to circumstances but always strives to continue to live amid intense competition among HE institutions.

\subsubsection{Improve the Quality of Service}

Public services are a series of activities provided by HE to the community in improving the quality of community life. As a form of responsibility to the community, HE must provide public services that cover all people who need them. The most important thing is how people are satisfied with the services offered to them. Therefore, HE entrepreneurial bureaucracy will always improve the community's assistance to make them comfortable and loyal to the organization. HE must create policies that support the implementation of improving public services to the community. The issuance of policies regarding the improvement of available services will encourage effective, efficient, and accountable service quality.

\subsubsection{Accountable}

A significant entrepreneurial value that characterizes the entrepreneurial HE bureaucracy is the accountable. Accountability of HE bureaucracy means that the bureaucracy provides information to the public openly to make them able to see the bureaucracy activities directly without being covered up, both in terms of management to finance. Accountability of HE bureaucracy is important to increase public trust to HE and to decrease the general suspicion of them.

\subsubsection{Empower the Community}

Many bureaucracies intentionally keep the community from developing to make them do not understand their actions in society. HE bureaucracy with entrepreneurial insight does the opposite. They always make the community smart and empowered to work together with institutions to improve the bureaucracy's performance. A bureaucracy that empowers the community means a bureaucracy that makes them elegant and has sufficient knowledge about the institution and its runs. This community empowerment is essential for HE bureaucracy with entrepreneurial insight. The community was invited to improve the bureaucracy's performance to make the community's services better.

\subsubsection{Be Professional}

HE bureaucracy with entrepreneurial vision runs its bureaucracy professionally, which follows the established procedures without selective logging. Professional means following the rules. Many bureaucracies provide services unprofessionally, such as unclear job descriptions, uncertain service time, and only concerned with individual people's interests. They prioritize certain people who considered necessary while ordinary people set aside and not served well. HE bureaucracy with a professional vision of entrepreneurship does not distinguish people from their status, rank, and wealth but helps them based on existing procedures. Anyone served with the same service must follow established procedures.

\subsubsection{Customer-oriented}

In the business world, the customer is the center and purpose of company activities. Without customers, a company is meaningless. Therefore, the company orientates its operations to satisfy customers and provide the best services for its customers. Likewise, HE bureaucracy with entrepreneurial insight will provide the 
best service to its customers, both internal and external. Therefore, efforts to improve the quality of services to customers must increase the customers' satisfaction. HE bureaucracy with entrepreneurial insight is not arrogant in itself, as is the case with most government bureaucracies. They made their customers kings who must always be spoiled, respected, and shaped like kings. This attitude makes entrepreneurial HE bureaucracy improve its services to the community and satisfy HE's services.

\subsection{Strategies for Implementing Entrepreneurial Values in HE Bureaucracy}

In this chapter, the study directed at how the tertiary institution's strategy in implementing entrepreneurial values in its bureaucracy. Based on the results of the analysis conducted by researchers on the data obtained from the field, the researcher found several strategies carried out by HE in implementing entrepreneurial values in bureaucratic development. The procedure described as follows:

\subsubsection{Formulate HE Vision and Mission Adaptive to the Change}

Vision and mission are important elements for higher education institutions as the direction of where the institution is headed. The initial step taken by HE with an entrepreneurial perspective is to formulate HE's vision and mission in accordance with the circumstances of the times. This change in vision and mission needs to give HE clear directions and goals, so that all members of the organization can direct all their activities in accordance with the vision and mission. Through renewable vision and mission, higher education institutions can direct all their movements and breath in the direction that is appropriate to the situation and conditions of society.

\subsubsection{Stimulate the Entrepreneurial Mindset of Bureaucracy}

The next step taken by the three HE in implementing entrepreneurial values in the development of $\mathrm{HE}$ bureaucracy is to build an entrepreneurial mindset on $\mathrm{HE}$ bureaucracy. The leaders are required to introduce and instill the values of entrepreneurship to HE academicians, ranging from students, employees, to lecturers. These entrepreneurial values must be socialized to them and build a system that ensures they can implement these values in the bureaucracy.

\subsubsection{Encourage Innovative Culture}

For the entrepreneurial values that have been instilled to the members of the organization to run well, it requires a creative culture as a field for the implementation of entrepreneurial values, because innovation and entrepreneurship are two things that support each other. Innovative culture makes it easy for institutions to implement changes towards a more productive work environment. Innovative culture provides a large space for institutions to instill entrepreneurial values in the HE bureaucracy.

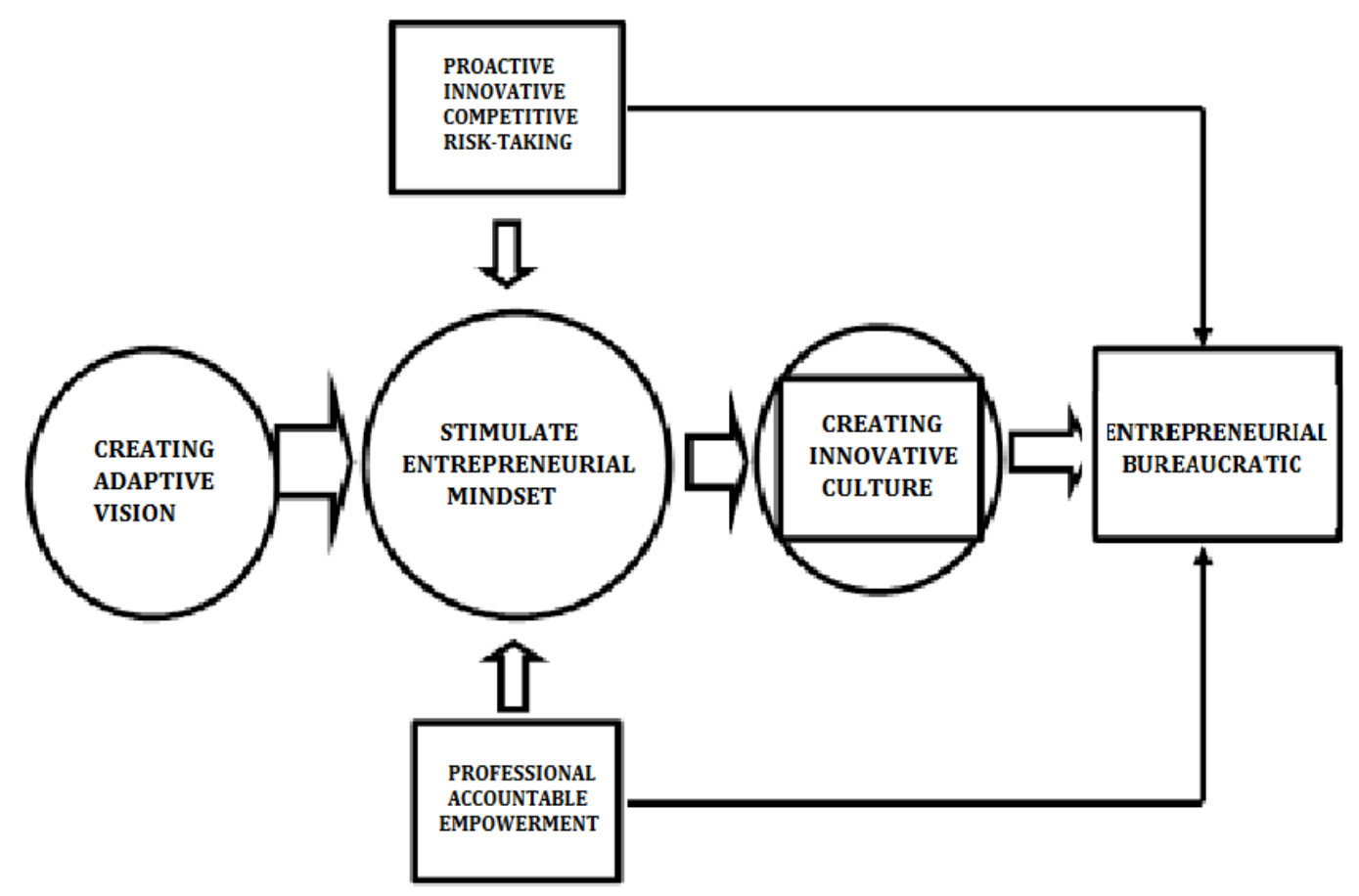

Figure 2. Strategies for creating entrepreneurial bureaucratic in HE 


\section{Discussion}

This study found several entrepreneurial values used by HE to support campus development. Based on the data observed found that those several values implemented in increasing the performance of the bureaucracy. The entrepreneurial values are innovative, proactive, risk-taking, customer orientation, professionalism, competitive, service quality improvement, accountability, and empowerment.

In general, these values are in line with several previous studies that explain the characteristics of the entrepreneurial spirit [30], [44]. The entrepreneurial values found in the research universities are values that are believed to be able to encourage the growth and development of higher education. With these entrepreneurial values, Higher Education tries to move the entire system, to make entrepreneurship as a jargon in campus development, so they dare to declare themselves into Entrepreneurial University [31]. Not only in curriculum development, but in all aspects of management, they try to apply the principles of entrepreneurship, by making new innovations, even though they have to bear a great risk [45]. The HE movement to implement proportional tuition fees, for example, is a very bold step in the management of State Universities. Although initially faced with great challenges from students and society, in the end students (the public) were able to accept the policy.

One of the entrepreneurial values found in $\mathrm{HE}$ researched is proactive value. This value is essential for rationalizing bureaucracy [46]. The application of entrepreneurial values in HE is seen in a variety of policies relating to campus development. For example, when issues arise about higher education management's autonomy, they respond to the system by preparing themselves to become legal entities. However, these efforts have not been successful until this research carried out their actions in responding to government policies used as one of the proactive evidence of HE in responding to the times' issues.

The entrepreneurial values held by the campus academics can make them like entrepreneurs who run a business [35]. They strive to develop their tertiary institutions in an innovative, creative, and courageous manner [31]. Conversely, if the entrepreneurial values do not underlie the spirit of tertiary institutions' development, the growth and development of tertiary institutions will be slow and lagging.

Another significant entrepreneurial value that is made by higher education researched in improving college performance is innovation. The HE has to do various innovations in various things, ranging from vision and mission, academic aspects to financial management. From the point of vision and mission, they changed their vision and mission from Research University to Entrepreneurial University.

This finding accepts the opinion of Sterling [47], who said that the change occurred because of innovations made by business people or entrepreneurs. If someone moves, he will encourage others to change, which ultimately creates innovations and increases profits and business activities. In the view of Schumpeter (1947), innovation is the main criterion of entrepreneurship. According to him, innovation is doing something new or doing something that already exists or has been done by someone else in a new way. The words "new way" is a creative response to the situation.

There are at least three characteristics of this creative response: First, practically, the creative response cannot be understood by others at that time. Second, creative responses lead to further events and have outcomes that are far ahead. Third, creative responses relate to (a) the personal qualities that exist in society, (b) the quality that exists for a particular field of activity, (c) individual decisions, actions, and behavior patterns. Therefore, the study of creative responses in business is closely related to the study of entrepreneurship. Thus according to him, a manager can be called an entrepreneur if he makes a creative or innovative response [48].

Empirically what was done by the leaders in the universities was studied, supporting the opinions of Shumpeter [48], Hagen [49], and McClelland [50] above. The development of the three HE observed in the last three years looks very fast compared to other universities in the same city due to the entrepreneurial spirit of the three universities' entrepreneurial spirit in developing the campus. Entrepreneurship values had spurred the three researched tertiary institutions to become the leading universities in Indonesia when many tertiary institutions experienced a decline and setback.

\section{Conclusions}

The analysis and discussion above concluded that universities in improving their bureaucratic performance apply many entrepreneurial values. Among these are innovative, proactive, risk-taking, customer orientation, professionalism, competitiveness, service quality improvement, accountability, and empowerment, resulting in direction. The application of entrepreneurial values to the higher education bureaucracy can improve organizational performance. Higher education bureaucracies, which are usually rigid and inflexible, can turn into adaptive and responsive administrations if they apply the entrepreneurial values in their environment.

The strategies adopted by the three tertiary institutions researched in implementing entrepreneurial values to improve bureaucratic performance are (1) developing a proactive vision and mission with the change, (2) instilling entrepreneurial values in the members of the organization, and (3) creating an innovative work environment. If universities apply these three strategies to provide services to their customers, they will succeed in driving the 
bureaucracy from traditional bureaucracy to entrepreneurial bureaucracy.

\subsection{Recommendation}

This study provides an overview of how HE strategies in applying entrepreneurial values in improving bureaucratic performance. The results showed that implementing entrepreneurial values in the bureaucracy needed the right approach to achieve the objectives. This study's results imply the importance of applying these entrepreneurial values in the higher education bureaucracy to bring higher education bureaucracy to perform well.

It recommended that university managers not get caught up in the rigid and stagnant Weberian bureaucracy but should try to breakthroughs out the administration by applying entrepreneurial values in the bureaucracy to perform better.

It recommended that future researchers measure which factors are the most influential in improving higher education bureaucracy performance? And does the application of entrepreneurial values in the bureaucracy have a positive effect on bureaucratic performance? If further research is carried out, it is expected to complete the gap that is lacking in this study.

\section{REFERENCES}

[1] P. Laredo, "Revisiting the third mission of universities: toward a renewed categorization of university activities?," High. Educ. Policy, vol. 20, no. 4, pp. 441-456, 2007.

[2] M. Sánchez-Barrioluengo, "Articulating the 'three-missions' in Spanish universities," Res. Policy, vol. 43, no. 10, pp. 1760-1773, 2014.

[3] J. A. Perkins, The university in transition. Princeton University Press, 2015.

[4] G. Peeke, Mission and Change. Institutional Mission and Its Application to the Management of Further and Higher Education. ERIC, 1994.

[5] J. V. Baldridge, D. V. Curtis, G. P. Ecker, and G. L. Riley, "Alternative models of governance in higher education," Gov. Acad. Organ., pp. 2-25, 1977.

[6] Imhe, Higher Education Management: Volume 11 Issue 3. Washington; Biggleswade: Organization for Economic Cooperation \& Development Turpin Distribution Services Limited [distributor, 2000.

[7] H. D. Graham, "Short-Circuiting the Bureaucracy: Policy Origins in Education.," 1981.

[8] H. G. Rainey, "On the Uniqueness of Public Bureaucracies," State Public Bur. Armonk ME Sharpe, pp. 112-140, 1992.

[9] R. Harms, C. H. Reschke, S. Kraus, and M. Fink, "Antecedents of innovation and growth: analysing the impact of entrepreneurial orientation and goal-oriented management," Int. J. Technol. Manag., vol. 52, no. 1/2, pp. 135-152, 2010.

[10] J. Caspersen, N. Frølich, and J. Muller, "Higher education learning outcomes-Ambiguity and change in higher education," Eur. J. Educ., vol. 52, no. 1, pp. 8-19, 2017.

[11] M. Wolverton, M. L. Wolverton, and W. H. Gmelch, "The impact of role conflict and ambiguity on academic deans," $J$. High. Educ., vol. 70, no. 1, pp. 80-106, 1999.

[12] E. Gross and P. V. Grambsch, University goals and academic power. Amer. Counc. on Educ, 1968.

[13] Y. V. Butova, N. N. Khan, L. P. Illarionova, and A. Moldazhanova, "Characteristics of Art Higher Education Institution Students' Social Competence," Int. Educ. Stud., vol. 8, no. 3, p. p212, Feb. 2015, doi: 10.5539/ies.v8n3p212.

[14] M. W. Migin, M. Falahat, M. S. A. Yajid, and A. Khatibi, "Impacts of Institutional Characteristics on International Students' Choice of Private Higher Education Institutions in Malaysia," High. Educ. Stud., vol. 5, no. 1, p. p31, Jan. 2015, doi: 10.5539/hes.v5n1p31.

[15] D. Tjosvold and L. T. McNeely, "Innovation through communication in an educational bureaucracy," Commun. Res., vol. 15, no. 5, pp. 568-581, 1988.

[16] H. Mintzberg, "1979 The structuring of organizations. Englewood Cliffs, NJ: Prentice-Hall,” 1979.

[17] I. R. Mirzanti, T. M. Simatupang, and D. Larso, "Mapping on entrepreneurship policy in Indonesia," Procedia-Soc. Behav. Sci., vol. 169, no. 20, pp. 346-353, 2015.

[18] H. Verheul, "Higher education reform in Indonesia," in The Theory and Practice of Institutional Transplantation, Springer, 2002, pp. 185-198.

[19] I. Remaja and N. Gede, "Penerapan Good Governance Dalam Tata Kelola Penyelenggaraaan Dan Pengelolaan Perguruan Tinggi Swasta Yang Berbasis Pelayanan," in Dalam Prosiding Seminar: Revitalisasi Tata Kelola Perguruan Tinggi, 2017, pp. 27-40.

[20] E. Sakapurnama, M. Huseini, and P. D. Soeling, "Building Entrepreneurial University: Case from HEI's in Indonesia," Univers. J. Educ. Res., vol. 7, no. 12, pp. 2747-2754, 2019.

[21] M. Abduh, A. Maritz, and S. Rushworth, "An evaluation of entrepreneurship education in Indonesia: A case study of Bengkulu University," Int. J. Organ. Innov., vol. 4, no. 4, pp. 42-43, 2012.

[22] L. Aldianto, G. Anggadwita, and A. N. Umbara, "Entrepreneurship education program as value creation," $J$. Sci. Technol. Policy Manag., 2018.

[23] A. M. Mahendra, E. T. Djatmika, and A. Hermawan, "The Effect of Entrepreneurship Education on Entrepreneurial Intention Mediated by Motivation and Attitude among Management Students, State University of Malang, Indonesia.," Int. Educ. Stud., vol. 10, no. 9, pp. 61-69, 2017.

[24] A. Yulastri and H. Hidayat, "Developing an Entrepreneurship Module by Using Product-Based Learning Approach in Vocational Education.," Int. J. Environ. Sci. Educ., vol. 12, no. 5, pp. 1097-1109, 2017. 
[25] A. Qurtubi, "REINVENTING THE ISLAMIC HIGHER EDUCATION HUMAN DEVELOPMENT TO INDONESIA COMPLETELY,” 2012.

[26] K. Saefullah, "FROM MICROFINANCE TO "GINTINGAN": $\quad$ REINVENTING LOCAL INSTITUTIONS FOR POVERTY REDUCTION IN INDONESIA," PEOPLE Int. J. Soc. Sci., vol. 4, no. 1, 2018.

[27] E. Sakapurnama, M. Huseini, and P. D. Soeling, "Reinventing higher education institution toward 4.0 industry era: Modelling entrepreneurial university in Indonesia," 2020.

[28] P. Drucker, "Entrepreneurship in business enterprise," J. Bus. Policy, vol. 1, no. 1, pp. 3-12, 1970.

[29] A. COLE, "Business enterprise in its social setting.: Harvard University Press. Cambridge, Mass,” 1959.

[30] J. A. Hornaday and J. Aboud, "Characteristics of successful entrepreneurs 1," Pers. Psychol., vol. 24, no. 2, pp. 141-153, 1971, doi: https://doi.org/10.1111/j.1744-6570.1971.tb02469.x.

[31] B. R. Clark, "Delineating the character of the entrepreneurial university," High. Educ. Policy, vol. 17, no. 4, pp. 355-370, 2004.

[32] H. Stroup, Bureucracy in Higher Education. New York: Free Press, 1966.

[33] M. Murphy, "Bureaucracy and its limits: accountability and rationality in higher education," Br. J. Sociol. Educ., vol. 30, no. 6 , pp. $683-695,2009$, doi: $10.1080 / 01425690903235169$.

[34] B. R. Clark, "The entrepreneurial university: Demand and response," Tert. Educ. Manag., vol. 4, no. 1, pp. 5-16, 1998.

[35] M. Lazzeroni and A. Piccaluga, "Towards the Entrepreneurial University," Local Econ., vol. 18, no. 1, pp. 38-48, Jan. 2003, doi: 10.1080/0269094032000073807.

[36] D. Osborne, "Reinventing government," Public Product. Manag. Rev., pp. 349-356, 1993.

[37] R. C. Bogdan, Biklen.(1998). Qualitative Recearch for Education: An Introduction to Theory and Methods. Allyn and Bacon. Boston. London, 86.
[38] J. Mason, "Qualitative Research," Sage, p. 234, 2002.

[39] A. Thoyib, G. Maskie, and K. Ashar, "Entrepreneurial characteristics as a mediation of entrepreneurial education influence on entrepreneurial intention," Editor. Rev. $B O A R D$, vol. 19, no. 1, p. 24, 2016.

[40] R. P. Suropaty, M. Maskur, and E. D. Wahyuni, "Sistem Informasi Manajemen Layanan SMS Center Universitas Muhammadiyah Malang," Kinet. Game Technol. Inf. Syst. Comput. Netw. Comput. Electron. Control, vol. 1, no. 2, pp. 91-100, 2016.

[41] M. I. Esha, "THE PHILOSOPHY ON INSTITUTIONAL CHANGES OF STATE ISLAMIC HIGHER EDUCATION (PTKIN) INTO UNIVERSITY," ULUL ALBAB J. Studi Islam, vol. 19, no. 1, Art. no. 1, Jun. 2018, doi: 10.18860/ua.v19i1.4801.

[42] E. Namey, G. Guest, L. Thairu, and L. Johnson, "Data reduction techniques for large qualitative data sets," Handb. Team-Based Qual. Res., vol. 2, no. 1, pp. 137-161, 2008.

[43] J. W. Creswel, Research design: Qualitative, quantitative, and mixed methods approaches. Los angeles: University of Nebraska-Lincoln, 2009.

[44] L. Schjoedt, "Entrepreneurial job characteristics: An examination of their effect on entrepreneurial satisfaction," Entrep. Theory Pract., vol. 33, no. 3, pp. 619-644, 2009.

[45] X. Liu, J. Stoutenborough, and A. Vedlitz, "Bureaucratic expertise, overconfidence, and policy choice," Governance, vol. 30, no. 4, pp. 705-725, 2017.

[46] J. T. Karr, "The rise of proactive police strategies: an alternative approach to bureaucratic rationalization and rural-urban crime differentials," University of Kansas, Sociology., 1978.

[47] S. Sterling, Sustainable Education: Re-Visioning Learning and Change. Schumacher Briefings. ERIC, 2001.

[48] J. A. Schumpeter, "The creative response in economic history," J. Econ. Hist., vol. 7, no. 2, pp. 149-159, 1947.

[49] E. E. Hagen, "The Economics of Development (Irwin, Homewood, Illinois)," 1980.

[50] D. C. McClelland, Achieving society. Simon and Schuster, 1961. 